\title{
ICT Competence and Needs of Turkish EFL Instructors: The Role of Gender, Institution and Experience
}

\author{
Özdenur Ardıç a * (D), Hatime Çiftçi b $†$ (D) \\ a National Defense University, Naval Academy, Heybeliada Campus, İstanbul, 34973, Turkey \\ ${ }^{b}$ Bahçeşehir University, Faculty of Educational Sciences, Foreign Language Education, İstanbul, 34353, Turkey
}

Received 02 October 2018 | Received in revised form 02 January 2019 | Accepted 07 March 2019

\begin{abstract}
APA Citation:
Ardıç, Ö., \& Çiftçi, H. (2019). ICT competence and needs of Turkish EFL instructors: The role of gender, in stitution and experience. Eurasian Journal of Applied Linguistics, 5(1), 153-173. Doi: 10.32601/ejal.543791
\end{abstract}

\begin{abstract}
This study aimed to scrutinize Information and Communication Technology (ICT) competence of English as a Foreign Language (EFL) instructors in Turkey and their professional development (PD) needs in ICT in relation to the variables of gender, institution, teaching experience, and their past PD experience. This study also explored the types of training sources EFL instructors preferred to further their PD in ICT. The data were collected by administering a questionnaire of ICT competence and PD needs of teachers. The participants were 193 EFL instructors teaching at various universities in Turkey. The data were analyzed by using IBM SPSS Statistics (i.e. Mean, Standard Deviation, ANOVA, Mann-Whitney U and Kruskal-Wallis test). The results indicated that EFL instructors perceived their current ICT competence as low in the seven major areas. However, gender and previous PD experience in ICT played a role in their perceived ICT competence. The study also revealed that regardless of gender, type of institution, previous PD experience in ICT, and teaching experience, EFL instructors reported a medium and higher amount of ICT training needs. The most preferred modes of PD in ICT were immersion or internship activities while the least preferred modes of PD were workshops/conferences/seminars. The implications of the study are also presented.
\end{abstract}

(C) 2019 EJAL \& the Authors. Published by Eurasian Journal of Applied Linguistics (EJAL). This is an open-access article distributed under the terms and conditions of the Creative Commons Attribution license (CC BY-NC-ND) (http://creativecommons.org/licenses/by-nc-nd/4.0/).

Keywords: Professional Development (PD) Needs; Information and Communication Technology (ICT); EFL Teachers; Technology Integration.

\section{Introduction}

Information and Communication Technology (ICT) refers to technologies that provide access to information through telecommunication. These include the Internet, wireless networks, cell phones, and other communication mediums. In alignment with the increased digitalization in education, ICT has evidently become the main

\footnotetext{
* Corresponding author.

E-mail address: ozdenurardic@gmail.com

${ }^{\dagger}$ hatime.ciftci@es.bau.edu.tr
} 
ingredient of the integration where effective and efficient teaching/learning processes are guaranteed as it enables significant functions for both educators and learners. The use of ICT in education has even become a must for today's teachers in order to provide students with technology-supported learning opportunities and schools have been integrating ICTs into their curriculums for the last twenty years (AduwaOgiegbaen, 2009). More specifically, the integration of ICT into second language learning is particularly important as it is a genuine need for students who grow up with such technologies in the 21 st century while learning (Chapelle, 2010). In second language learning, the use of ICT provides many benefits, such as immediate feedback, instant interaction, boosted motivation, and access to authentic resources in and outside the classroom. ICT use also facilitates the opportunities for engaging in intercultural communication and similar encounters (Ibrahim, 2010).

ICT use in language learning and teaching obviously necessitates effective planning and design even more than other fields. One major element in this is undoubtedly the teacher herself/himself. As articulated by Smith and Hanson (2000), technology in education begins and ends with teacher. ICT and computers will remain as only electronic devices unless teachers use them efficiently in classroom practice. Teachers are the ones who transform these electronic devices into useful educational materials. Thus, the power to change or adapt new conditions relies on teachers' development (Ovens, 1999).

There is no doubt that ICT affects the roles and practices of English as a Foreign Language (EFL) teachers in the sense that traditional approaches to language teaching are replaced with the new student-centered approaches; new roles for both teachers and students are set. This requires teachers to be equipped with ICT resources and skills, and be able to teach the content in subject matter while incorporating technology concepts and skills. However, because of tangible and intangible barriers, teachers are not able to extensively exploit ICT. For tangible factors, it is generally about having limited or no access to ICT tools and facilities or shortly physical conditions. But there are numerous intangible factors that are in relation with attitudes, motivations, and beliefs of teachers and learners. This study aims to explore both sides by focusing on the use of ICT by the EFL teachers, professional development (PD) needs of EFL teachers in ICT and their preferred modes of PD in ICT. Besides, it also aims to highlight future prospects and bring some recommendations for public policy making in education.

\subsection{ICT in education}

Applying the modern technology in-class and out-of-class activities has gained momentum and become trendy since millennium. Computers, digital technology, and Internet as a combined force of forming effective learning environment refine the processes of learning and teaching, where students have been engaged in getting knowledge and applying it in an active, self-directed, and constructive environment (Hismanoğlu, 2015; Volman \& Van Eck, 2001). After computers have been introduced, 
related items such as scanners, printers, floppy disks and drivers have also been exposed to the market. Then, the concept of Information Technology (IT) has become so widely used in economy and public institutions that the sub-units of those have started to include IT departments in their organization structures. Following this, the Internet and smart technologies boomed and have been brought together with the World Wide Web (WWW), networks, search engines, and e-mails. Thus, along with emphasis on communication through such technologies, the term 'IT' has turned into 'ICT' to better express the connection between technology and its affordances for communication. One of the most important features of ICT is that learning and teaching can be time-independent and place-independent. Thanks to technology, everybody can access information any time they want without boundaries of time and place. This makes learning lifelong.

Shawcross (2004) remarked the things that technology is able to bring along in language teaching as these factors: "greater availability, accessibility, and flexibility, integration of media and linguistic skills, constant access to authentic material, reaching larger and remote populations, speech samples and accents, appropriate content matter, feedback and monitoring, enhanced learner involvement and motivation, new classroom dynamics" (p. 2). It is possible to ascertain that while there are these benefits of technology in language teaching, it is worth saying that the future of education is lying on the roads of technological development.

It has been stated by Davis (2006) that computers cannot change things positively without having trainers and educators. Schrum (2000) has also argued that technological knowledge and expertise do not take place in a quick way or by having access to it. Rather, it should be learnt and applied. UNESCO (2011) has reported that having gained basic ICT skills is never enough. A teacher today has to be able to make use of technology in the process of teaching so that the learning process can be as interactive as possible and responding to the learner's needs. Therefore, teachers are the ones who will enable collaborative environment to be creative learners through applying necessary ICT tools.

\subsection{Implementation of ICT in Turkey}

There has been a significant step to prompt up education with technology in Turkey. Since the beginning of 21th century, Ministry of National Education (MoNE) has invested in ICT to facilitate and enrich teaching. Some schools were provided with ICT classrooms, education software, computers, overhead projectors, printers and Internet connection (Gülbahar \& Güven, 2008). The latest attempt of MoNE to increase ICT support in schools was projected as Movement of Enhancing Opportunities and Improving Technology (presented as FATIH project). It started in 2010 with an overall aim to promote equality in education and efficient use of technology and communication tools. By setting an ICT infrastructure in schools, 570.000 classrooms were equipped with interactive white boards, multi-functional 
printers and broadband Internet connection. Besides, all the students and teachers were provided with a tablet PC.

MoNE has been working on a website to use as an Education and Information Network called EBA (http://www.eba.gov.tr/). It aims to broadcast free electronic resources for effective use of ICT tools in classrooms. What is more, besides electronic resources EBA offers videos, images, audios, e-books, discussion groups and educational software to all communities of education. Furthermore, MoNE has launched a school system as a portal. This portal is used by both foundation and public schools for any kind of administrative purpose. Parents are now able to follow their children's progress at this online platform. Following this, MoNE has come up with the educational software DynEd, which is the abbreviation for Dynamic Education and has been used in language teaching in primary and secondary schools since 2007-2008 academic year. Respectively its use has been compulsory for all levels of schools and students as a supplement to their English lessons since then.

However, Uzun (2015) proposed that teacher training programs (TTP) in Turkey have been largely technologically investigated and modified starting from their establishment, but in parallel to this there has been a mislead or incapacity to apply theory. That is why, the Turkish education system in its technology captivation has faced crucial problems in applying the theory. For instance, integrating ICT into education was a global trend in which technology-backed education was implemented by traditional means and materials. More controversially, the space has been equipped with modern technologies but the mentality of the teachers and learners has not changed enough to activate the change. What is more, TTPs and curriculums have not been updated in an innovative way to alter the educational viewpoints of the teachers and learners. That is to say, there has been a little or limited effort to realize the ideological change from traditional base to digital or innovative base. The current English Language Teacher Training Programs (ELTTP) seem not to be close to having a technologically collaborative, updated, and innovative content. These programs in general comprise traditional approaches, methods, materials, and procedures combined with outdated knowledge.

\subsection{Integration of technology in English language teacher education in Turkey}

Providing insights into the integration of technology in education in Turkey, Akçaoğlu (2008) investigated the technology integration approaches and practices of 120 in-service and 62 pre-service English language teachers working at foundation universities in Ankara. First, he defined the level of their involvement with the computers in their activities, their computer expertise, perceived barriers behind applying ICT and their attitudes towards computers. He also examined the educational value they attained to ICT exploitation in their language teaching practice and their personal ideas of effective integration. He pointed out that teachers make use of computers at their schools at limited times; the findings also indicated that they had higher levels of instructional computer usage outside the school. 
Although these teachers thought that technology would help make their lessons more student centered, they believed applying ICT as a teacher tool rather than a student tool would help them foster higher thinking skills and better learner autonomy.

More recently, Selvi (2015) indicated that participants regarded ICT as a valuable tool and maintained interest in developing their ICT capabilities. In his study, the researcher developed a questionnaire to be applied to 103 participating EFL teachers working in Artvin and its towns. Following the questionnaire, he conducted semistructured interviews with 10 participants to examine EFL teachers' use of ICT in their classroom practice. The study indicated that EFL teachers were mostly found to use ICT mostly in classroom and home activities for drill and practice, and also in explaining new information and doing presentation of student works.

The abovementioned studies presented several drawbacks with regard to ICT use and integration to EFL instruction. First, none of the courses promoted the ICT knowledge and/or skills of teachers and trainees at a sufficient level. Second, the pedagogical knowledge given to the participants did not corroborate with the technical knowledge, which actually should have eased the application of pedagogical skills with the technological developments. Finally, these studies proved that the inadequate technical expertise and weaker technical skills would cause avoidance of technology use and development higher education.

\subsection{Need for PD of EFL teachers with the use of ICT}

With the use of technology, teachers' roles turn into monitors and facilitators by having less control over transmitting knowledge and this makes learners to be interactive in receiving information (Lamtara, 2014). Hence, the use of technology in the classroom necessitates EFL teachers to use technology effectively to improve their students' language proficiency in English and requires them to be knowledgeable in ICT in order to integrate them into the curriculum in a way that aims to raise their academic development. Previous research on teachers' use of ICT in educational institutions has also indicated that the reason why they fail in the practice of ICT in classes is closely linked to little effort or very few resources available for professional development of teachers (Aduwa-Ogiegbaen, 2009). The majority of EFL teachers express that the most important professional development need is teaching English with ICT and to use new technologies in the workplace (Marin, 2015).

According to the study of Akbaba-Altun (2006), one of these problems is the insufficient in-service training courses for teachers, especially in content areas. Training courses are provided by unqualified trainers and are not appropriate for teachers' needs and levels; besides these in-service training courses also have a lack of hands-on activities and are not offered for school principals and teachers.

Chen (2008) had also made an observatory study on 311 EFL teachers in higher education entities in Taiwan and tested their Internet use in their teaching, and the possible factors that fall behind in the use of the Internet. The results showed that the majority of the teachers (80\%) employed the Internet use in their teaching. 
Furthermore, it was proven that seven different factors as expertise, external support, perceived capability, beliefs, attitudes, the constructive thinking, and classroom pedagogy had correlated to the use of Internet. However, the teacher's expertise was the most directly affecting factor on the Internet use.

In a research study administered by Karakaya (2010), the attitudes of English language teachers towards computer and their use of technology in language teaching were explored. The results of the study indicated that almost all of the teachers had positive opinions for integrating technology in language teaching. Nonetheless, they had hard times in integrating technology into their instruction effectively since they did not have professional training on integrating technology into education. Thus, he proposed that in order to make prospective teachers competent in ICT skills in language instruction, pre-service English language teacher education programs should provide technology related courses for their students. It is also recommended that teachers should be provided with in-service training on technology integration in order to realize effective use of technology in education.

Özdemir (2013) took the central premise of his doctoral project to improve the preservice English Language Teachers' ICT skills and to help them develop positive attitudes towards the use of ICT in classroom teaching. With regard to this, an online course was attained. The researcher made use of three tools to collect data from 27 participants as fourth grade pre-service students of English Language Faculty of a university in Turkey. The tools named as 'Computer Technologies Survey' and 'ICT Can Do List' were prepared as pre-test and post-test to depict the change in their attitudes towards ICT, computer self-efficacy and computer technology literacy. The last tool was a semi-structured interview that was employed to get some useful information about the perceptions of the participants on the use of ICT in teaching English. The outright results showed that the treatment of giving an online educational technology course to them did not really have an important impact on the attitudes and self-efficacy of the pre-service teachers about applying ICT in the classroom.

In spite of an increased interest in the use of technology in English Language Teaching (ELT), little empirical research has been conducted in this line of scope, especially from the perspectives of in-service English language teachers' needs in ICT. The studies done so far generally focus on teachers' perceptions on using ICT in their teaching or attitudes toward ICT integration into language instruction and very few studies have been conducted on alternative solutions to empower EFL teachers with the necessary knowledge about ICT through hands-on practice. In the light of the unquestionable importance of ICT in EFL education, the present study focuses on Turkish in-service EFL instructors' PD needs in ICT. First, their technology competence is examined and then their PD needs pertaining to the use of technology in the classroom are investigated. Lastly, the modes of PD preferred by the instructors are identified. The study also aims to provide implications for addressing such PD needs of in-service language teachers in Turkey as well as recommendations 
for further research. Thus, the present study seeks to reach the aforementioned purposes by addressing the following questions:

1. What is the level of ICT competence of EFL instructors in Turkey?

2. What are the desired ICT training/professional development needs of EFL instructors?

3. What are the preferred modes of professional development of EFL instructors?

\section{Method}

\subsection{Research design}

The current study was conducted through quantitative research methods based on the questionnaire of ICT competence and professional development needs of teachers. This non-experimental research provides numeric description of opinions of a population by studying a sample of that population (Creswell, 2014). In this context, EFL instructors' general ICT competence levels and their PD needs were analyzed on the basis of the variables of gender, place of work (state or foundation university), teaching experience and their past PD experience in ICT and their preferred modes of professional development were determined by interpreting the mean scores.

\subsection{Setting and participants}

The population of the present study consists of Turkish in-service EFL instructors who worked at English preparatory schools of 6 state and 5 foundation universities in Turkey in 2017-2018 academic year. The number of people in the sample population was 193 EFL instructors working at different foundation and state universities in İstanbul, Ankara, İzmir, Kocaeli and Yalova in Turkey. They taught EFL to different levels of learners and their teaching experience ranged from 1 to more than 12 years at the time of data collection. Sampling design of the target population was decided as convenience sampling because participants were chosen regarding their willingness to be part of this study and their availability (Fraenkel \& Wallen, 2003). The demographic information of the participants is presented in Table 1 in number and frequencies. 
Table 1. Demographic features of the participants

\begin{tabular}{llll}
\hline & Variables & $N$ & $\%$ \\
\hline Gender & Female & 122 & 63 \\
Place of Work & Male & 71 & 37 \\
& State University & 123 & 64 \\
Teaching Experience & Foundation University & 36 & 64 \\
& $1-3$ years & 60 & 31 \\
4nstructors having PD in ICT & 4-6 years & 43 & 22 \\
Instructors having no PD in ICT & $10-12$ years & 37 & 19 \\
& More than 12 years & 22 & 11 \\
& Yes & 31 & 16 \\
\hline
\end{tabular}

\subsection{Instrument}

The modified questionnaire in this study was originally developed by AduwaOgiegbaen (2009) to investigate Nigerian in-service teachers' self-assessment in core technology competence and their professional development needs in ICT. To test the adequacy of the questionnaire, it was revised and a Likert-type scale from 1-4 with ratings aligning with evaluations was adapted as a 5-point Likert-type scale for the current study. All of the items in the questionnaire were adopted. After adaption of the Likert-type scale in the questionnaire for present study, a quantitative analysis of the investigation was implemented to statistically test the reliability of the research instrument. Therefore, each section of the questionnaire was tested with Cronbach alpha coefficient, and for Section B .95, for Section C .98, and for Section D .85 were obtained as reliability coefficients, which showed a strong reliability of the data collection tool. Also, the researcher who designed the questionnaire was informed about using the questionnaire in the research study via e-mail.

The questionnaire in the current study has four sections with 61 items in total. Section A consisted of demographic information of the participants including gender, place of work, teaching experience and whether they have received any training in the use of computers in the past three years. In Section B, respondents were asked to indicate their level of professional skills they have in ICT areas through 25 items. Section C required participants to identify the quantity of training they need in 27 ICT skill areas. In Section D of the questionnaire, the participants were asked to indicate their preferred modes of professional development and rate their preferred professional development modes according to whether they are very high, high, medium, low, or none in their scale of preference.

\subsection{Data collection}

Prior to the data collection, certain steps were followed for ethical concerns. First, heads/directors of Foreign Languages departments/schools were contacted via e-mail 
and permissions for the application of the questionnaire were obtained. The data collection involved delivery of questionnaires both as hard copies and online. In both formats, the participants were informed about steps for administering the questionnaire through the informed consent letter as the initial page of the questionnaire. Before starting to fill in the questionnaire, they were asked to accept that they willingly consent to participate in this research. The return rate for the completion of the questionnaire was $80 \%$ of the intended participants $(n=193)$.

\subsection{Data analysis}

The data collected through questionnaires were analyzed using SPSS 22. Prior to the analysis, the missing data pattern was checked and it was found that the data were missing at random and thus incomplete observations were replaced with new data using an expectation-maximization (EM) algorithm. In the entire dataset, 193 participants' rates for Section B, 182 participants' rates for Section C, and 146 participants' rates for Section D were evaluated because of the missing data. Before examining group differences, the skewness and kurtosis statistics were checked for normality and Levene's test was examined for equality of the variances. It was concluded that the data met the normality assumption for some groups as the standard error was between -1.96 and +1.96 in skewness and kurtosis values. In Levene statistics, as significant $\mathrm{p}$ value shows heterogeneity of variances, it was regarded to be more than 0.05 to meet the homogeneity of variances. When the assumptions were satisfied, one-way analysis of variance (ANOVA) was used for comparing more than two groups. For the groups in which there is violation of normality and equal variance assumption, the non-parametric tests (Mann-Whitney $\mathrm{U}$ and Kruskal-Wallis test) were performed to compare group differences. The .05 level of significance is adopted for the whole data analysis. For Section D, the mean scores of the eight items were calculated and shown by column chart.

\subsection{Limitations}

There are certain limitations in the present study. As the target population of the study is the in-service EFL instructors working at foundation and state universities in Turkey and the sample size of the study are limited to 193 EFL instructors, the findings may not be generalizable to the other EFL settings since the instructors' knowledge, past experience and working places might affect their professional and personal development needs in ICT. Hence, even though the situation might have similarities, the findings should be evaluated with caution while making comparisons as ICT needs in a certain social context might be quite different as well. Also, the scope of this study is English language preparatory programs at universities in Turkey. Future research should expand to K-12 educational settings, adult EFL/ESP programs at language institutions or similar settings in different cities in Turkey and other ELT contexts. 


\subsection{Delimitations}

This study also has a few delimitations. First, EFL instructors working at English preparatory schools at foundation and state universities were purposefully chosen since there are not many studies in the literature administered to English preparatory school instructors. The investigators also selected these participants since they were accessible and their characteristics seemed to be appropriate for the aim of the study. The universities in different cities were chosen regarding their availabilities. In addition to this, as the major data collection instrument, a selfadministered questionnaire was preferred in that it provides specific advantages, such as the economy of the design and the fast returns in data collection. Also it has the advantage of diagnosing dimensions of a large population from a small group of individuals (Babbie, 1990; Fowler, 1988 as cited in Creswell, 2014).

\section{Results}

\subsection{Research question 1: What is the level of ICT competence of EFL instructors in Turkey?}

The second section of the instrument in this study was used to answer the first research question. In order to measure EFL instructors' ICT competence, 25 items were posed. These 25 items were collapsed into seven major areas to get a clear indication as follows:

i) Word processing skills

ii) Spreadsheet skills

iii) Database skills

iv) Electronic presentation skills

v) Web/Internet navigation skills

vi) Graphic tools skills

vii) Integration skills

The mean scores and standard deviation values for ICT competence areas were calculated to analyze Research Question 1 and are given in Table 2.

Table 2. The mean and standard deviation values for ICT competence areas

\begin{tabular}{|c|c|c|c|c|c|c|c|}
\hline & $\begin{array}{l}\text { Word } \\
\text { Processing } \\
\text { Skills }\end{array}$ & $\begin{array}{l}\text { Spreadsheet } \\
\text { Skills }\end{array}$ & $\begin{array}{l}\text { Database } \\
\text { Skills }\end{array}$ & $\begin{array}{l}\text { Electronic } \\
\text { Presentation } \\
\text { Skills }\end{array}$ & $\begin{array}{l}\text { Web/Internet } \\
\text { Navigation } \\
\text { Skills }\end{array}$ & $\begin{array}{l}\text { Graphic } \\
\text { Tools } \\
\text { Skills }\end{array}$ & $\begin{array}{l}\text { Integration } \\
\text { Skills }\end{array}$ \\
\hline $\bar{N}$ & 193 & 193 & 193 & 193 & 193 & 193 & 193 \\
\hline Mean & 1.5538 & 1.7974 & 1.8275 & 1.7513 & 1.4272 & 1.9462 & 1.8290 \\
\hline $\begin{array}{l}\text { Std. } \\
\text { Deviation }\end{array}$ & .72122 & .80012 & .73748 & .81172 & .58424 & .92784 & .89953 \\
\hline
\end{tabular}


As can be seen in Table 2, the mean values for seven major skills range from 1.43 to 1.95 out of 5 . The table shows that EFL instructors assess themselves as having low skills in the seven major skills areas above.

Skewness and kurtosis values and Levene statistics showed that the data violated normality and equal variance assumption. To investigate group differences in terms of general ICT competence levels, Mann-Whitney U test for comparing two independent samples was used and Kruskal-Wallis test was performed.

Table 3. Mann-Whitney U test findings

\begin{tabular}{lcllcc}
\hline Variables & $N$ & Mean Rank & Sum of Ranks & U Statistic & $p$ \\
\hline Female & 122 & 90.11 & 10993.50 & 3490.50 & .025 \\
Male & 71 & 108.84 & 7727.50 & 3653.00 & .080 \\
$\begin{array}{l}\text { State } \\
\text { University }\end{array}$ & 123 & 102.30 & 12583.00 & & \\
$\begin{array}{l}\text { Foundation } \\
\text { University }\end{array}$ & 70 & 87.69 & 6138.00 & 3155.50 & .003 \\
$\begin{array}{l}\text { Having } \\
\begin{array}{l}\text { Professional } \\
\text { Development }\end{array}\end{array}$ & 69 & 80.73 & 5570.50 & & \\
$\begin{array}{l}\text { Having No } \\
\text { Professional }\end{array}$ & 124 & 106.05 & 13150.50 & \\
Development & & & & & \\
\hline
\end{tabular}

With the female EFL instructors having a mean rank of 90.11 and the male EFL instructors having a mean rank of 108.84, the Mann-Whitney $U$ test of difference shows that there is a significant difference between the male and female EFL instructors in their general ICT proficiencies $(p=.02<0.05)$. The male EFL instructors assess themselves more competent than female counterparts.

With the instructors in state universities having a mean rank of 102.30 and the instructors in foundation universities having a mean rank of 87.69, the MannWhitney $U$ test of difference shows that there is not any significant difference between instructors in state and foundation universities in terms of their general ICT proficiencies $(p=.08>0.05)$. In other words, EFL instructors in both state and foundation universities do not differ in terms of ICT competence levels.

As for the EFL instructors with previous professional development experience (a mean rank of 80.73) and EFL instructors without previous professional development experience (a mean rank of 106.05), the Mann-Whitney $U$ test shows that there is a significant difference between the EFL instructors with and without professional development in their general ICT proficiencies $(p=.003<0.05)$. The EFL instructors with previous professional development experience asses themselves more competent in ICT than English language instructors without any previous professional development experience.

To investigate if there is any significant difference between EFL instructors with regard to their teaching experience in terms of general ICT competence levels, a non- 
parametric test called Kruskal-Wallis test was performed. Table 4 shows KruskalWallis test findings.

Table 4. Kruskal-Wallis test findings

\begin{tabular}{llllll}
\hline Teaching Experience & $N$ & Mean Rank & $d f$ & Chi-Square & $p$ \\
\hline 1-3 years & 60 & 95.82 & 4 & 2.322 & .677 \\
4-6 years & 43 & 92.56 & & & \\
7-9 years & 37 & 92.15 & & \\
10-12 years & 22 & 98.52 & & \\
More than 12 years & 31 & 110.16 & & \\
\hline
\end{tabular}

With the instructors' groups (1-3 years, 4-6 years, 7-9 years, 10-12 years and more than 12 years experience) having a mean rank of 95.82, 92.56, 92.15, 98.52 and 110.16 respectively, the Kruskal-Wallis test of difference shows that there is not any significant difference between instructor groups having different teaching experience years in terms of their general ICT proficiencies $\left(x^{2}=2.322, p=.677>0.05\right)$. In other words, EFL instructors having different experience do not differ in terms of their ICT competence levels.

\subsection{Research question 2: What are the desired ICT training / professional development needs of EFL instructors?}

To determine EFL instructors' training/development needs, third section of the questionnaire consisting of 27 items was used. Mean scores and standard deviation values were used in order to answer the second research question. The means and the standard deviations for the items in the questionnaire are given in the Table 5.

As can be seen in Table 5, the items in the questionnaire have a mean score of 3.0 out of 5 and above, showing that EFL instructors need a medium and high amount of training/professional development in these areas. To be more precise, Table 5 shows that EFL instructors need a medium training/professional development in 5 out of the 27 ICT areas and need high amount of training/professional development 22 out of the 27 ICT areas. 
Table 5. The mean and standard deviation for the items

\begin{tabular}{|c|c|c|c|}
\hline Items & $\mathrm{N}$ & Mean & Std. Deviation \\
\hline 1. Create a document on a word processor & 182 & 3.5714 & 2.67724 \\
\hline 2. Operate computers and usebasic software for word processing & 182 & 3.4547 & 1.50403 \\
\hline 3. Create effective computer-based presentations & 182 & 3.3077 & 1.45422 \\
\hline 4. Access information on CD-ROM & 182 & 3.5934 & 1.54832 \\
\hline 5. Search the Internet for resources & 182 & 3.4451 & 1.68344 \\
\hline 6. Integrate ICT tools into student learning activities in my teaching subject & 182 & 3.1152 & 1.31009 \\
\hline 7. Evaluate educationalsoftware & 182 & 2.9945 & 1.20082 \\
\hline 8. Advanced input/output devices-scanner, digital camera & 182 & 3.1154 & 1.35959 \\
\hline 9. ICT for school management grading, attendance, student records. & 182 & 3.1203 & 1.46450 \\
\hline $\begin{array}{l}\text { 10.Electronic research using Internet and other online recourses to enhance } \\
\text { my research }\end{array}$ & 182 & 3.2527 & 1.50941 \\
\hline 11. Create multimedia documents to support instruction & 182 & 3.1429 & 1.38717 \\
\hline 12. Accessing and sending e-mail & 182 & 3.5604 & 1.70283 \\
\hline 13. PowerPoint presentation & 182 & 3.3681 & 1.61884 \\
\hline 14.Using computers forgrading and producing assignments for my students & 182 & 3.2527 & 1.44584 \\
\hline 15. Evaluateand usecomputersandrelated ICT tools for instruction & 182 & 3.1067 & 1.30326 \\
\hline 16. Desktop publishing & 182 & 3.1461 & 1.25967 \\
\hline 17. Drill/practice programs/tutorials & 182 & 3.1209 & 1.31574 \\
\hline 18. Use of spreadsheet for several instructional applications & 182 & 3.1462 & 1.30274 \\
\hline 19. Use of word processor for my written professional works & 182 & 3.2637 & 1.44769 \\
\hline 20. Use of graphicsin my word processing or presentations & 182 & 3.2161 & 1.30437 \\
\hline $\begin{array}{l}\text { 21. Set up my computer andperipheral devices, loadsoftware, print anduse } \\
\text { operating system tools }\end{array}$ & 182 & 3.1489 & 1.36446 \\
\hline $\begin{array}{l}\text { 22. To organize my files, locate files quickly, and back up my files tofloppy } \\
\text { disk or other storage devices }\end{array}$ & 182 & 3.2802 & 1.48046 \\
\hline 23. To manipulate/analyze/interpret data and perform calculations & 182 & 3.1498 & 1.26357 \\
\hline 24. Tocreate models or simulations & 182 & 2.9176 & 1.22984 \\
\hline $\begin{array}{l}\text { 25. To use metasearch tools and subject directories (Google, Internet, public } \\
\text { library, Yahoo) to locate materialsin my subject area }\end{array}$ & 182 & 3.2659 & 1.51171 \\
\hline $\begin{array}{l}\text { 26. Use presentation devices (video data projector, scan converter/monitor, } \\
\text { document camera) for classroom presentation }\end{array}$ & 182 & 3.1868 & 1.47099 \\
\hline 27. To demonstrate ethicalusage of ICT materials (e.g., software) & 182 & 3.1012 & 1.26684 \\
\hline
\end{tabular}

Before examining group differences, to see if the data is dispersed in a normal distribution way, the skewness and kurtosis statistics were checked and Levene's test was examined again. It was found that the data did not turn up normally distributed in terms of gender, types of institution, and having PD or not. Therefore, the data was analyzed with Mann-Whitney U test. 
Table 6. Mann-Whitney U test findings

\begin{tabular}{lccccc}
\hline Variables & $N$ & Mean Rank & Sum of Ranks & U Statistic & $p$ \\
\hline Female & 113 & 91.41 & 10329.00 & 3888.00 & .976 \\
Male & 69 & 91.65 & 6324.00 & & .462 \\
State & 120 & 93.56 & 11227.50 & & \\
University & & 87.51 & 5425.50 & & .148 \\
$\begin{array}{l}\text { Foundation } \\
\text { University }\end{array}$ & 62 & 99.08 & 6440.50 & & \\
$\begin{array}{l}\text { With } \\
\text { Professional }\end{array}$ & 65 & & & & \\
$\begin{array}{l}\text { Development } \\
\text { Without }\end{array}$ & 117 & 87.29 & 10212.50 & & \\
Professional & & & & & \\
Development & & & & & \\
\hline
\end{tabular}

With the female EFL instructors having a mean rank of 91.41 and the male EFL instructors having a mean rank of 91.65, the Mann-Whitney U test shows that there is no significant difference between the male and female EFL instructors in their professional development needs $(p=.976>0.05)$. In other words, the female and male EFL instructors are identical in terms of professional development.

With the instructors in state universities having a mean rank of 93.56 and the instructors in foundation universities having a mean rank of 87.51, the MannWhitney $U$ test shows that there is no significant difference between instructors in state and foundation universities in terms of their professional development needs $(p=.462>0.05)$. In other words, EFL instructors in both state and foundation universities do not differ in terms of professional development needs.

As for the EFL instructors with ICT professional development having a mean rank of 99.08 and EFL instructors without ICT professional development having a mean rank of 87.29, the Mann-Whitney $U$ test shows that there is not significant difference between them in their professional development needs $(p=, 148>0.05)$. The EFL instructors with professional development and without professional development are identical in terms of their professional development needs.

Regarding skewness and kurtosis values and homogeneity variances, the data distribution was found normal regarding teaching experience of the EFL instructors in this study. Therefore, one-way ANOVA test was performed to see if there is any significant difference between EFL instructors with regard to teaching experience in terms of professional development needs. 
Table 7. One-way ANOVA test findings

\begin{tabular}{llllll}
\hline Teaching Experience & Sum of Squares & $d f$ & Mean Square & $F$ & Sig. \\
\hline Between Groups & 907.916 & 4 & 226.979 & .213 & .931 \\
Within Groups & 188834.035 & 177 & 1066.859 & & \\
Total & 189741.950 & 181 & & & \\
\hline
\end{tabular}

According to the values shown in Table 7 , no statistically significant difference was found between instructor groups having different experience years in terms of their professional development needs $(F=.213, p=.931>0.05)$. In other words, English language instructor groups having different experience do not differ in terms of professional development needs.

\subsection{Research Question 3: What Are the Preferred Modes of Professional Development of} EFL Instructors?

To determine preferred professional development mode, Section D of the questionnaire consisting of 8 items was used. The mean scores were used in order to answer this research question. The means of the rates to the eight items in Section D range from 2.26 to 2.68 and were shown by column chart in Figure 1.

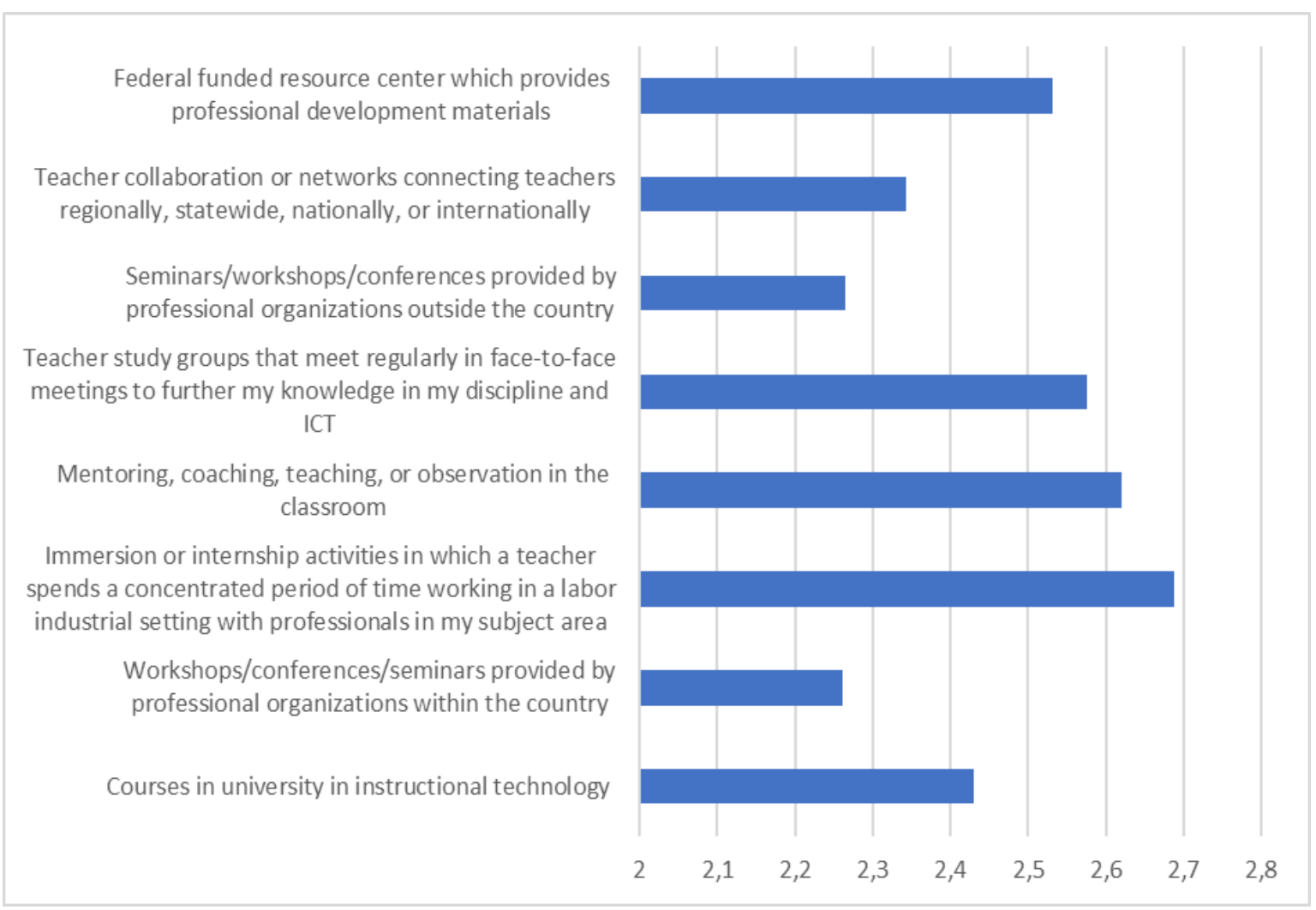

Figure 1. The preferred modes of PD of EFL instructors

As Figure 1 demonstrates, the most preferred mode of professional development by Turkish EFL instructors is immersion or internship activities in which a teacher spends a concentrated period of time working in a lab or industrial setting with 
professionals in his/her subject area. These are followed by receiving mentoring, coaching, lead teaching, or observation in the classroom and teacher study groups that meet regularly in face-to-face meetings to further their knowledge in their discipline and ICT respectively. The least preferred mode is workshops/conferences/seminars provided by professional organizations within the country.

\section{Discussion}

This study aimed to address three research questions on ICT competence of Turkish EFL instructors. The first research question examined the level of ICT competence of these instructors with regard to the variables of gender, type of institution (foundation or state), teaching experience, and previous professional development experience. The findings showed that EFL instructors assessed themselves as having low skills in the seven major skills areas, such as the word processing facilities, spreadsheet facilities, database facilities, web/Internet facilities, electronic presentation skills, graphic tools, and integration skills. One reason for this might possibly be the bias of teachers who are used to teaching English by using traditional methods and this might lead such a perception of having low ICT competence. In Efaw's (2005) study, for instance, it was claimed that little has been done to prepare reluctant teachers for the computers found in the classrooms in a three-phase program aiming to help novice instructors in incorporating technology into the classroom. The similar finding was echoed in the study conducted by AduwaOgiegbaen (2009) investigated Nigerian in-service teachers' self-assessment in core technology competence and found that the majority of the in-service teachers have a less than satisfactory level of ICT competence and only few of the in-service teachers have high and medium skills in integrating ICT into the curriculum.

This study has also indicated that gender plays a role in the reported ICT competence of Turkish EFL instructors as the male EFL instructors assessed themselves more competent than female counterparts. Besides, this study demonstrated that there was a significant difference in favor of the EFL instructors having personal development in ICT before. In the light of this finding, it was concluded that having PD in the use of computers in the past was proved to have positive influence on their professional skills in ICT areas. This was also in line with the research administered by Chen (2008) who found out that the teacher's expertise and experience in ICT training was a positive factor affecting ICT usage directly. The reason for the significant difference was related to the importance of the development of appropriate pedagogical practices in ICT.

The second research question in this study aimed to examine the desired ICT training/professional development needs of Turkish EFL instructors. The findings revealed that Turkish EFL instructors express a need for a considerable amount of professional development in key ICT areas. Previously, certain reasons were associated with ICT professional development needs of teachers, such as unavailable or insufficient ICT, poor or nonexistent Internet connectivity, lack of technical 
support, and little effort or too few resources available for professional development of teachers (Aduwa-Ogiegbaen, 2009). In spite of the heavy investment in ICT facilities and professional development for teachers, the majority of teachers has not yet grasped new pedagogical practices and do not have confidence yet in exploiting ICT to support new approaches in teaching (Silva, 2007). In this study, the reported need for ICT professional development in key technological skills by EFL instructors is important and the findings should be considered a call for a systematic and welldesigned ICT in-service teacher education program. This study also corroborates with previous research in the sense that in-service teachers are willing to acquire more skills and experience through pedagogical and technical training in ICT (Mulholland, 2006; Sang, Valcke, van Braak, Tondeur, \& Zhu, 2010) to be able to integrate ICT effectively into their classroom practices.

It is obvious that in-service EFL instructors in this study are willing and ready to acquire ICT skills. It can be understood that in-service instructors who are open to change through on-going education are willing to try new ideas in the classroom. When eager instructors are given the opportunity to learn new technology skills and techniques, they most probably will show increase in their competence.

The second research question in this study also investigated the desired ICT training/professional development needs of Turkish EFL instructors in terms of gender, type of institution, teaching experience, and their having PD in ICT or not. Overall, these variables did not make any difference in the desired ICT training/professional development needs of Turkish EFL instructors. Thus, this study contributes to the line of ICT research indicating that the length of teaching experience, whether being a novice or an experienced teacher, does not play a role in EFL instructors' need to improve themselves on the personal and professional level (Solmaz, 2011). Although a few studies argue that teaching experience is a significant factor affecting technology integration (Akçaoğlu, 2008; Saklavcı, 2010), this study provides evidence for the necessity of ongoing in-service ICT teacher training programs regardless of the amount of experience in the profession.

The third research question in this study examined EFL instructors' preferred modes of ICT professional development. The findings demonstrated that EFL instructors mostly prefer to gain practical skills through pedagogical practices focusing on subject mastery, management skills, and use of various teaching tools, including ICTs rather than theoretical knowledge. This suggests that the development of appropriate pedagogical practice is more important than technical mastery of ICTs for them. The literature related to this research question also provides relevant support by putting forward the idea that the factors to be considered by community leaders and public policy makers have changed as teachers' roles change. As a result of that, EFL instructors are increasingly in need of in-service training support programs for the pedagogical use of ICT in language teaching (Kalogiannakis, 2010). There is no doubt that such training provides a strong base for teachers' continuing learning and growth in ICT use in their instruction. Regular attendance at immersion and internship activities, doing mentoring, coaching, 
teaching in the classroom and meeting teacher study groups may provide more ongoing professional development activities than one-time-only workshops (Lorenzo, 2002; Wang, 2006; Zhou, 2007). These activities enhance improved teacher skills in the classroom by facilitating improved student performance.

\section{Implications and recommendations}

The questionnaire responses revealed some implications for in-service EFL instructors' training and program designers in the field. Firstly, EFL instructors assessed themselves as being deficient in seven key ICT competence areas consisting of word processing skills, spreadsheet skills, database skills, electronic presentation skills, web/Internet navigation skills, graphic tools skills and integration skills. The statistical data showed that the male EFL instructors assessed themselves more competent than female counterparts. Also, the analysis of the first research question illustrated that EFL instructors having professional development assessed themselves more competent in ICT competence than English language lectures having no PD. It can be understood from these findings that the difference in ICT competence levels arose between the instructors having PD and other instructors having no PD in ICT because of their CALL knowledge. In that sense, those who feel more self-confident with ICT use and abilities should take a leading role among their colleagues and motivate them. One way to establish such a support system for ICT development for in-service teachers should be collaborative action research studies as a part of the training program. The school/university administrations and program designers should definitely consider the facilitation of such teacher research in ICT.

Secondly, the analysis of the second research question showed that EFL instructors needed a medium training / professional development in 5 out of the 27 ICT areas and needed high amount of training /professional development in 22 out of the 27 ICT areas. We can understand from that result most of the EFL instructors are in need of training in order to use ICT more effectively although they generally know how to use the computer and can benefit from it in various ways. Hence, ICT training courses can be organized for the ELT teachers/instructors and pedagogical training on how to use ICT for communicative purposes should be offered through good examples of effective integration of technology to language learning and teaching. Thus, they should be informed about the efficient use of ICT in the class. Even if a school is equipped with technological devices such as overhead projectors, computers, labs, and smart boards, teachers should be trained for the integration of ICT to use them effectively during the lessons.

Third concrete implication of the study is the top professional development modes preferred by EFL instructors. The data gathered from the research demonstrated that immersion or internship activities in which a teacher spends a concentrated period of time working in a lab or industrial setting with professionals in his/her subject area is the most preferred mode among EFL instructors in Turkey. That is to say, EFL instructors should be equipped with ICT skills and appropriate training on when and 
how to use ICT tools appropriately in classroom situations. To realize this, ICT professional development should be an ongoing effort and the focus of professional training in ICT should emphasize the practical aspects such as how to apply and integrate appropriate technologies into the curriculum.

In conclusion, this study indicates that in-service EFL instructors in Turkey are not competent in many skill areas in ICT. That is why they indicated a medium and high level of need for professional development in the ICT skill areas. The major implication of this study is that making technology relevant for teachers is required in designing professional development program for teachers, and the main areas include skills for using the Internet, ability to locate relevant Web sites and level-appropriate materials, and knowledge to incorporate ICT materials into teaching and learning. Based on the findings, following recommendations are made:

- All in-service EFL instructors should have minimum proficiency in the using software, basic word processing, database, and spreadsheet functions.

- They should learn how to use the Internet to search for relevant materials for their lessons.

- These in-service instructors need pedagogical skills, such as classroom management skills needed for mentoring and coaching, to create student-centred learning environments by developing innovative ways of technology use for efficient teaching and learning.

- Authorities should provide educational institutions with equal access of computer technology by distributing government-funded materials.

- Instructors should be provided with scholarships and some motivation to acquire knowledge and skills in ICT. It may include sponsorship of them for immersion and internship activities in higher degree programs coordinated with university professionals.

\section{Acknowledgements}

We must offer our sincere thanks to all the participants for their willingness to take part in this study. We are also thankful to two anonymous reviewers for their invaluable comments and feedback.

\section{References}

Aduwa-Ogiegbaen, S. E. (2009). Nigerian in-service teachers' self-assessment in core technology competence and their professional development needs in ICT. Journal of Computing in Teacher Education, 26(1), 17-28.

Akbaba-Altun, S. (2006). Complexity of integrating computer technologies into education in Turkey. Educational Technology \& Society, 9(1), 176-187.

Akçaoğlu, M. (2008). Exploring technology integration approaches and practices of pre-service and in-service English language teachers. Master thesis, Middle East Technical University, Ankara, Turkey.

Chapelle, C. A. (2010). The spread of computer-assisted language learning. Language Teaching, 43(1), 66-74. 
Chen, W., Tan, A., \& Lim C. (2012). Extrinsic and intrinsic barriers in the use of ICT in teaching: A comparative case study in Singapore. Proceedings of ASCILITE Australian Society for Computers in Learning in Tertiary Education Annual Conference, Wellington, 2012 (pp. 191-196).

Chen, Y. (2008). A mixed method study of EFL teachers' Internet use in language instruction. Teaching and Teacher Education, 24(4), 1015-1028.

Creswell, J. W. (2014). Research design: Qualitative, quantitative, and mixed methods approaches. Lincoln: Sage.

Davis, R. (2006). Utopia or chaos?: The impact of technology on language teaching. Teaching English with Technology, 6(4).

Efaw, J. (2005) No teacher left behind: How to teach with technology. Educause Quarterly, 4, $26-32$.

Fraenkel, J.R., \& Wallen, N.E. (2003). How to design and evaluate research in education(5th ed.). New York: McGraw-Hill.

Gülbahar, Y., \& Güven, I. (2008). A survey on ICT usage and the perceptions of social studies teachers in Turkey. Journal of Educational Technology \& Society, 11(3).

Hanson-Smith, E. (Ed.). (2000). Technology-enhanced learning environments. Alexandria, VA: TESOL.

Hismanoğlu, M. (2015). Turkish K-12 EFL teachers' attitudes toward ICT integration into language instruction. Journal of Educational \& Instructional Studies in the World, 5(1).

İbrahim, A.E. (2010). Information and communication technologies in ELT. Journal of Language Teaching and Research. 1(3), 211-244.

Kalogiannakis, M. (2010). Training with ICT for ICT from the trainee's perspective. A local ICT teacher training experience. Education and Information Technologies, 15(1), 3-17.

Karakaya, K. (2010). An investigation of English language teachers' attitudes toward computer technology and their use of technology in language teaching. MA thesis, Metu, Ankara.

Lamtara, S. (2014). Teachers' ICT practices: A case study of a Moroccan EFL teacher. Arab World English Journal, 5(4).

Lorenzo, c. (2002). ICT professional development for effective technology use. Retrieved from: http://www.schoolnet.ph/school/forummessage?-Id=7463\&forum-id=7413 $\quad$ on November 10, 2018.

Marin, E. (2015). Professional development on using ICT-an ongoing process. The International Scientific Conference e-Learning and Software for Education (Vol. 2, p. 236). " Carol I" National Defence University.

Mulholland, R. (2006). A technology snapshot: Teacher preparation program and the local public schools. Contemporary issues in Technology and Teacher Education, 6(2), 284-292.

Ovens, P. (1999). Can teachers be developed?. Journal of In-service Education, 25(2), 275-306.

Özdemir A. E. (2013). Improving pre-service English language teachers' ICT skills and developing positive attitudes towards the use of technology in language teaching through an online course. Master's Thesis, Çukurova University, Adana.

Saklavcı A. (2010). The Use of the internet among EFL teachers at high schools in Eskişehir. Master's Thesis, Anadolu University, Eskişehir.

Sang, G., Valcke, M., Braak, J., \& Tondeur, J. (2010). Student teachers' thinking processes and ICT integration: predictors of prospective teaching behaviors with educational technology. Computers \& Education, 54(1), 103-112.

Schrum, L. (2000). Technology as a tool to support instruction. Retrieved from: http://www.educationworld.com/a_tech/tech/tech004.shtml on December 29, 2017. 
Selvi, B., (2015). EFL teachers' use of information and communication technologies (ICT) in their classroom practice: Artvin sample. Master thesis, Atatürk Üniversitesi, Erzurum.

Shawcross, P. (2004). Technology in language teaching. Proceedings of the First ICAO Aviation Language Symposium, Montreal.

Silva, A. J. P. (2007). The impact report. Retrieved from: http://pshbwvcomputerssciencedepartment.blogspot.com/2007/12/ict-impact/report.html on November 7, 2017.

Solmaz, O. (2011). Liselerdeki İngilizce öğretmenlerinin kişisel ve mesleki gelişim için bilgi ve iletişim teknolojileri. Master thesis, Dicle University, Diyarbakır.

UNESCO, I.C.T. (2011). Competency framework for teachers. Paris: United Nations Educational, Scientific and Cultural Organization.

Uzun, L. (2015). The pedagogical courses in the ELT program in Turkish higher education: How efficient are they? International Journal of Social Sciences and Education, 5(4), 777789.

Volman, M., \& Van Eck, E. (2001). Gender equity and information technology in education: The second decade. Review of Educational Research, 71(4), 613-634.

Wang, Y. (2006) Stand-alone computer courses in teachers' IT training. EDUCAUSE Quarterly, 29(3).

Warschauer, M., \& Meskill, C. (2000). Technology and second language teaching. Handbook of undergraduate second language education, 15, 303-318.

Zhou, G. (2007). Adoption of educational technology ten years after setting strategic goals; A Canadian University case. Australian Journal of Educational Technology. 23(4), 508-528.

\section{Copyrights}

Copyright for this article is retained by the author(s), with first publication rights granted to the Journal. This is an open-access article distributed under the terms and conditions of the Creative Commons Attribution license (CC BY-NC-ND) (http://creativecommons.org/licenses/by-nc-nd/4.0/). 